\title{
Appropriate household point-of-use water purifier selection template considering a rural case study in western India
}

\author{
Ramprasad Venkatesha ${ }^{1} \cdot$ Anand B. Rao ${ }^{2} \cdot$ Shireesh B. Kedare ${ }^{3}$
}

Received: 3 February 2019 / Accepted: 17 April 2020 / Published online: 30 April 2020

(c) The Author(s) 2020

\begin{abstract}
There is a wide range of household water treatment options available for a variety of contexts. Each water purifier has its own optimal range of operation. Simultaneously, the diverse environments and circumstances set different boundary conditions for such purifiers to operate successfully. In low-income countries, especially with unregulated and decentralised water supply mechanisms such as open wells, the use of point-of-use water purifiers is quite widespread. However, it is observed that the water purifier may not be appropriate to the prevailing context. Hence, this short review aims to introduce a wide range of water purification alternatives available for a family (of about 3-5 members) and the way they could be classified and reviewed. The perspective selected is that of a low-income rural household in coastal region of western India and the scenario of water quality which is primarily affected by physical and biological impurities and not necessarily severe chemical contamination. Based on this context, attributes are defined and prioritised; further, a scale to rate the purifiers is worked out. A selected number of point-of-use water purifiers for which data from the literature or field observations are available are reviewed against these attributes for the sample context chosen. This independent review methodology consists of setting the attributes and comparing the water purifiers based on the sum of prioritised scores and thus acts like a selection template and can be adopted to select the appropriate purifier for any other scenario accordingly.
\end{abstract}

Keywords Water purifiers $\cdot$ Point-of-use $\cdot$ Review $\cdot$ Appropriate selection $\cdot$ Rural areas $\cdot$ Developing countries

\section{Introduction}

The global population which did not have access to safe drinking water in the year 2012 was around 700 million. With household treatment of water, it has been reported that diarrhoeal illnesses could be reduced by $30-40 \%$ (Sobsey et al. 2008). In India, it has been observed that $70 \%$ of the surface water is microbiologically and chemically contaminated. Further, more than $33 \%$ of ground water sources in rural India is claimed to be polluted (Water Pollution 2013).

Ramprasad Venkatesha

ramprasad07@gmail.com

1 BAIF Development Research Foundation, Pune 411058, India

2 Centre for Technology Alternatives for Rural Areas (CTARA), Indian Institute of Technology Bombay, Mumbai 400076, India

3 Department of Energy Science and Engineering (DESE), Indian Institute of Technology Bombay, Mumbai 400076, India
In rural areas due to the dispersed settlements, drinking water sources are usually decentralised in the form of dug wells, hand pumps or tube wells. Even in urban areas, despite the existence of centralised water supply, marginal communities may lack the access to such utilities or supply through such centralised systems may be prone to get contaminated. In such scenarios, household point-of-use water purifiers become indispensable. A review of such purifiers might be quite useful to zero in on the most suitable purifier for the prevailing context and hence this study.

Point-of-use purifiers which incorporate water treatment at or near the place of use are covered in the study. This study, primarily undertaken through the review of the literature, classifies and describes the different types of PoU purification alternatives for a family (of about 3-5 members). Based on the perspective of a rural household consuming water from a decentralised source, such as an open well in the coastal region of Maharashtra State in western India, the attributes used to compare the water purifiers are prioritised. Further, the study compares a selected number of point-ofuse purifiers across different attributes, for which relevant 
data from the literature and field observations were available. This independent reviewing approach, considering various references, helps in identifying the water purifier which gets the highest total score which is to be considered the appropriate water purifier for the prevailing scenario. Finally, this review comes up with some emerging inferences.

\section{Classification and description of point-of-use water purifiers}

\section{Classification of water purifiers}

The classification of purifiers has gradually evolved, and the description and methodology adopted in this review takes references from Peter-Varbanets et al. (2009) and Loo et al. (2012). The purifiers have been categorised into thermal- or light-based treatment techniques, physical removal methods, chemical treatment techniques and integrated water purification. Both sections on classification ("Classification of water purifiers" section) and description ("Description of purifier alternatives" section) cover a wide variety of water purification options; however, a special focus has been accorded to feasible options in the context of decentralised water sources prevalent in rural coastal areas in developing countries such as India. Most of the water purifiers in use or available in the market usually combine different treatment techniques and hence are integrated water purification methods. However, to make it clear to the reader the underlying water purification methodology, the classification in terms of the technique used for purification is adopted. The detailed classification chart is as shown in Fig. 1.

\section{Description of purifier alternatives}

\section{Thermal or light based treatment techniques}

Boiling Boiling is perhaps the oldest method of water purification (Sobsey 2002) but is a highly energy intensive one. One minute of boiling at a temperature $100{ }^{\circ} \mathrm{C}$ (at mean sea level) ensures neutralisation of faecal and thermo-tolerant coliforms, protozoan cysts and viruses (Sobsey 2002; Loo et al. 2012). Since boiling does not provide residual protection, boiled water needs to be kept in closed and clean containers and preferably consumed within $24 \mathrm{~h}$. The taste of water after boiling gets altered and is generally not easily adopted across all regions except in Asia due to sociocultural reasons (Lantagne and Clasen 2009).

Thermal pasteurisation In thermal pasteurisation, temperature usually does not go beyond $75^{\circ} \mathrm{C}$ which is suitable to eliminate E. coli by more than 5 LRV (Islam and Johnston 2006; Gupta et al. 2008). Coiled metal tubes can be retrofitted with cookstoves (Fig. 2) as in traditional earthen cook-
Fig. 1 Hierarchical chart depicting the classification scheme of the study

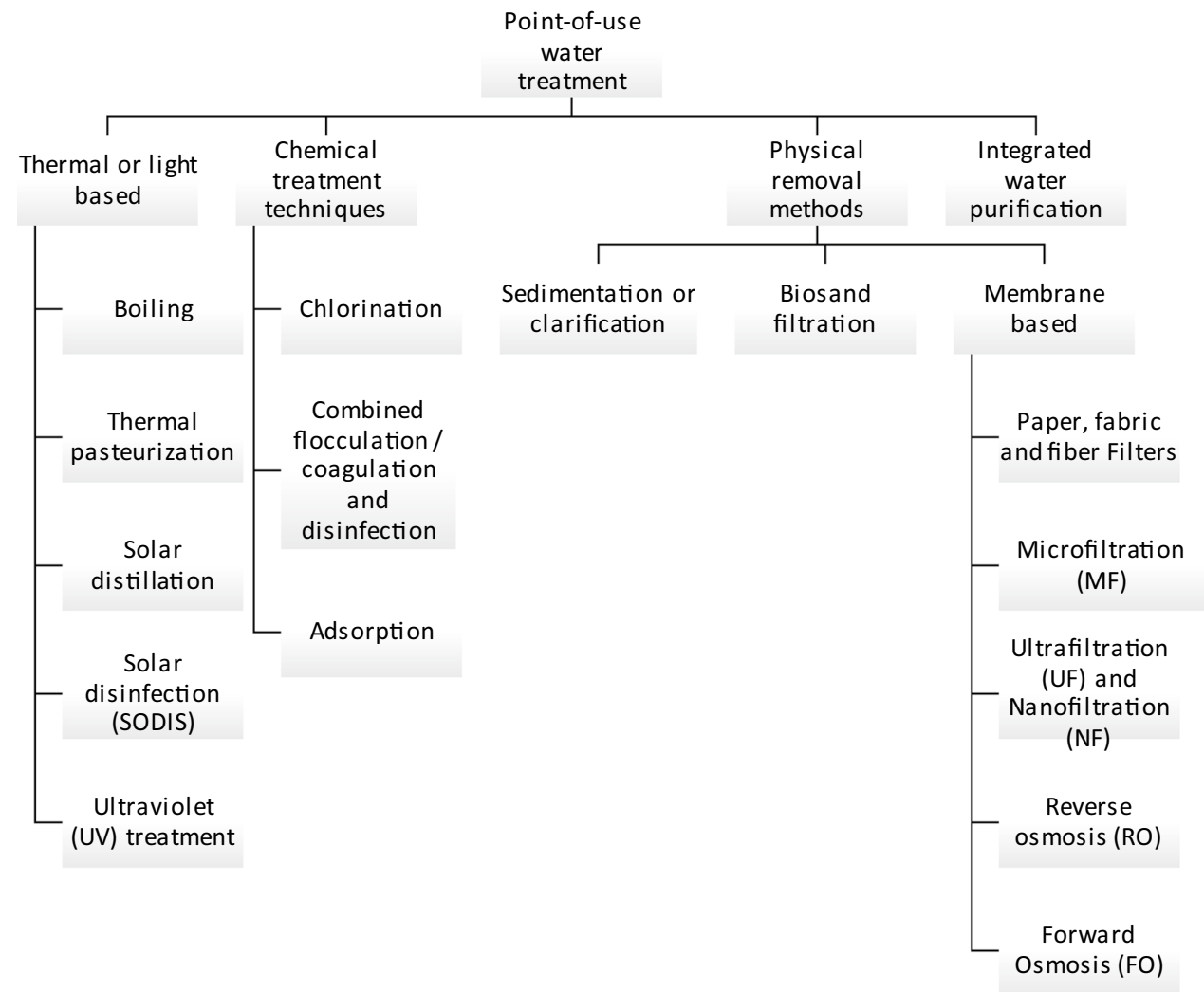




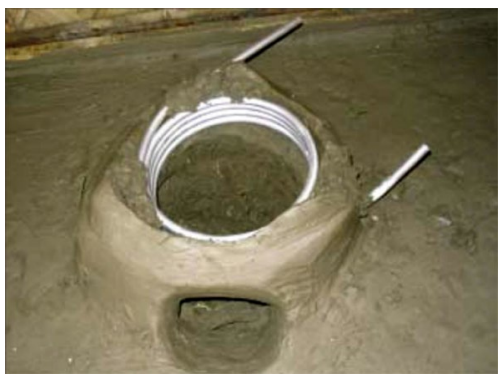

Fig. 2 Chulli purifier in the form of a coiled tube (Islam and Johnston 2006)

stove or Chulha in Chulli purifier or Lonera cookstove in water disinfection stove (WADIS). Due to its difficulty in use and mechanical issues, its adoption was limited in Bangladesh (Gupta et al. 2008; Loo et al. 2012).

It has been reported that up to $4 \mathrm{LRV}$ of faecal coliform and viruses could be removed using solar water heaters with solar irradiation of just $2 \mathrm{~h}$ on sunny days and $4 \mathrm{~h}$ on cloudy days (Kang et al. 2006; Loo et al. 2012).

Solar distillation Solar distillation combining the process of evaporation and distillation can be a convenient method for the removal of salts and non-volatile impurities using solar stills (Flendrig et al. 2009). Solar still consists of a vessel which holds the contaminated water and a transparent lid which aids condensation (Flendrig et al. 2009) (Fig. 3). This method involves large area, high upfront cost and low discharge rates of $0.5 \mathrm{~L} / \mathrm{d}$ to $3 \mathrm{~L} / \mathrm{d}$ (Flendrig et al. 2009; Loo et al. 2012).

Solar disinfection (SODIS) For low volumes of filtered water with turbidity of less than $30 \mathrm{NTU}$, water can be filled in transparent polyethylene terephthalate (PET) bottles (Fig. 4) and kept under sunlight for at least six hours after forceful shaking for aeration (Peter-Varbanets et al. 2009). SODIS can be an effective way to use heat and UV radiations from the sun to targets microbes. In case of low intensity of solar radiation, solar collectors or additives like lemon juice or vinegar can be used to improve the efficacy (Loo et al. 2010). SODIS has low operating costs involved because easy availability of PET bottles, however, has a long treatment time on low volumes of water.

Ultraviolet (UV) treatment For low turbid water UV treatment could be effective even on Crypto Giardia lamblia cysts and Cryptosporidium parvum oocysts by more than 3 LRV (Gadgil 1998; Berg 2010). UV systems generally rely on electrical power and do not offer residual protection (Berg 2010). Aquaguard Compact (Fig. 5) is an example of UV-based purifier (Aquaguard, 28.10.2014).

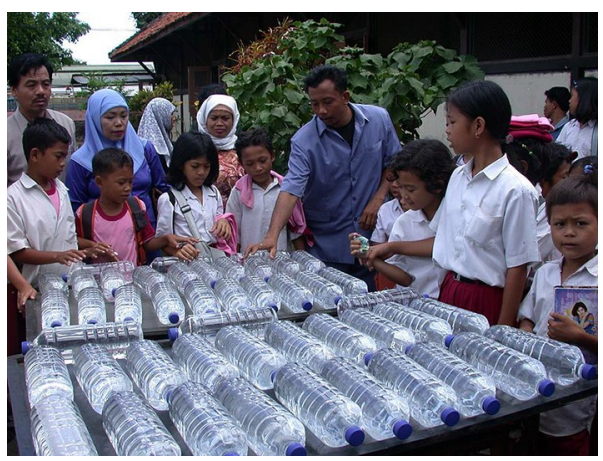

Fig. 4 SODIS in operation (SODIS, 20.11.2019)
Fig. 3 Conceptual sketch of a solar distillation unit (Loo et al. 2012)

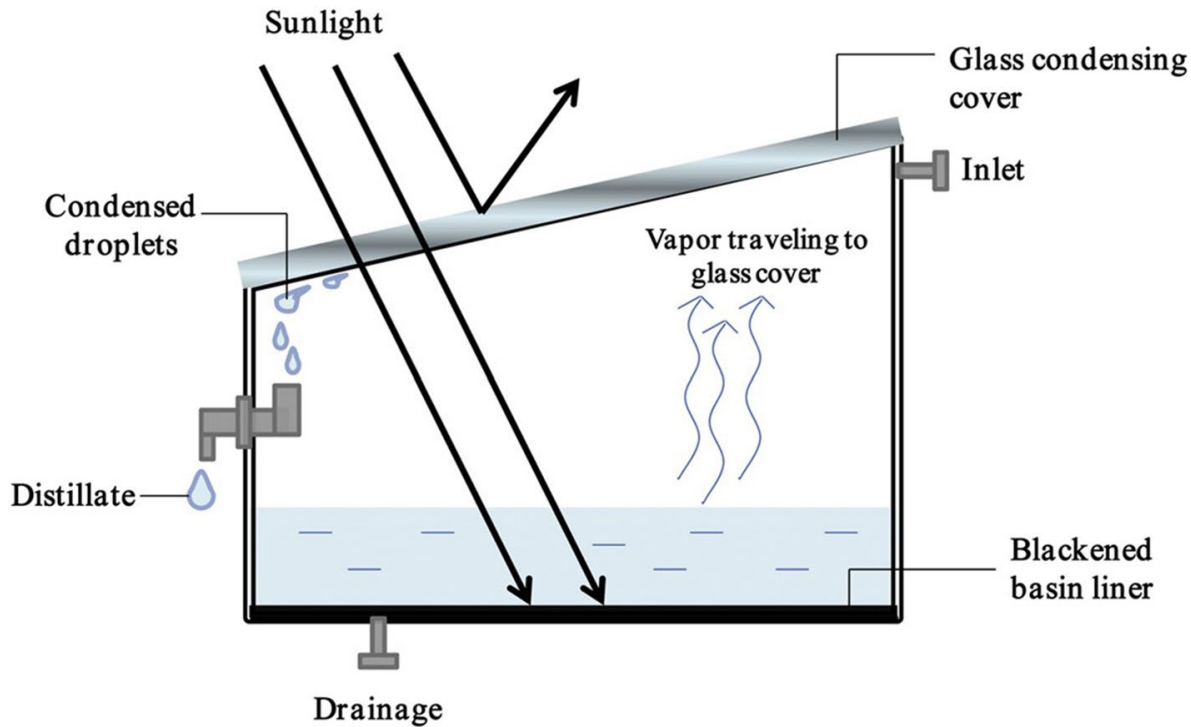




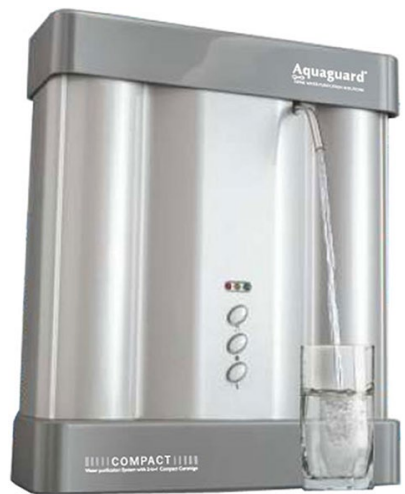

Fig. 5 Aquaguard Compact UV purifier (Aquaguard, 28.10.2014)

Fig. 6 Plastic bottle containing sodium hypochlorite solution. Photo: Darpan Das, based on special arrangement with the authors

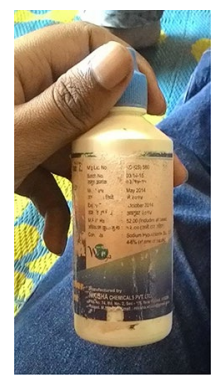

Fig. 7 Combined flocculantdisinfection (PUR) sachet (PUR, 31.10.2014)

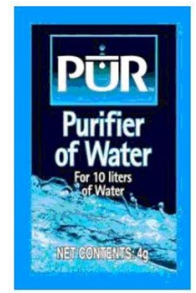

\section{Chemical treatment techniques}

Chlorination Chlorination is a simple, affordable and scalable method of water disinfection through the use of sodium hypochlorite $\mathrm{NaOCl}$ (liquid) (Fig. 6), $\mathrm{NaDCC}$ (solid) and calcium hypochlorite $\left(\mathrm{Ca}(\mathrm{OCl})_{2}\right)$ (solid). It gives residual protection due to the availability of free chlorine; however, there may not be any improvement in terms of turbidity. With a dosage of $2 \mathrm{mg} / \mathrm{L}$ for about $0.5 \mathrm{~h}$, chlorination can offer about 3 LRV of enteric bacteria (Gadgil 1998); however, there is the issue of generation of disinfection byproducts (DBPs).

\section{Combined flocculation/coagulation and disinfection (CFD/} CCD) For a reduction in turbidity as well as microbial disinfection, combined methods such as coagulant/flocculant as well as chemical disinfectant powders/tablets are used (Peter-Varbanets et al. 2009). These products (like PuR sachet in Fig. 7) combine calcium hypochlorite (or bleach)
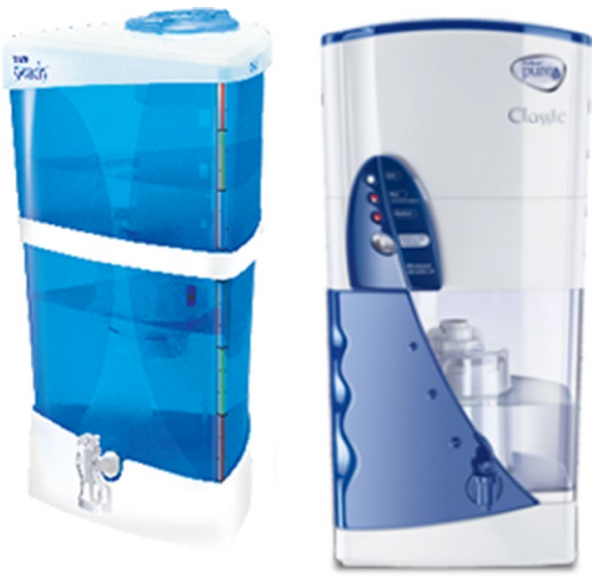

Fig. 8 Tata Swach Cristella Plus and HUL Pureit Classic (Swach, 28.10.2014; Pureit, 28.10.2014)

with coagulating agents like sodium carbonate and oxidisers like potassium permanganate. For $10 \mathrm{~L}$ of water, a PuR sachet of $4 \mathrm{~g}$ is added, stirred for $5 \mathrm{~min}$ and after sedimentation, and the water is filtered across a clean fabric and left undisturbed for $20 \mathrm{~min}$ for disinfection (CDC, 28.10.2014). The method could offer 7-9 LRV for bacteria, 2-6 LRV for viruses and 3-5 LRV for protozoa (Sobsey et al. 2008). Flocculation-disinfection also has the problem of taste and odour like chlorination but also involves higher cost, multiple steps and resources (Lantagne and Clasen 2009).

Adsorption To remove particulates, organic matter and chlorine/disinfectant leftovers, adsorbents like activated carbon are used. They are used in granulated form after disinfection methods like chlorination, UV, etc. like in commercial purifiers like Aquaguard Compact and HUL PureIt Classic (Aquaguard, 28.10.2014; Pureit, 28.10.2014) (Fig. 8). Biofilm growth compels frequent replacement of such cartridges (Peter-Varbanets et al. 2009). In Tata Swach, adsorption is through rice husk ash (activated silica and activated carbon) which is impregnated with silver nanoparticles to target microbes (Swach, 28.10.2014).

\section{Physical removal methods}

Sedimentation or clarification Clarifiers like alum, lime, iron, seeds of Moringa oleifera (drumstick) (Fig. 9) and seeds Strychnos potatorum (clearing nut or Nirmali tree) (Fig. 10), Guar gum and Jatropha curcas have been used to reduce turbidity through sedimentation (Ndabigengesere and Narasiah 1998; Sobsey 2002). There are also claims that Strychnos potatorum and aluminium salts (alum) and iron salts could help in reduction in microbial contamination by up to $95 \%$ and $99 \%$, respectively (Sobsey 2002; Khan et al. 1984). 


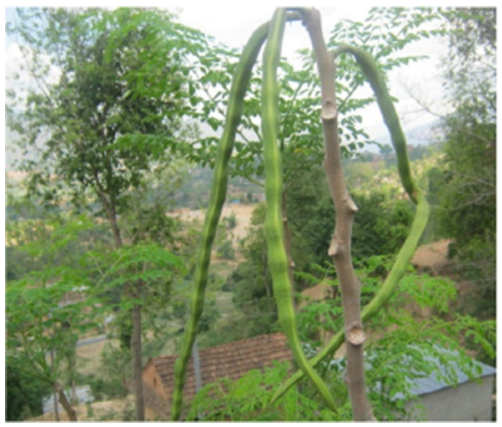

Fig. 9 Moringa oleifera tree and dried seed (unpeeled and peeled) (Moringa Tree, 30.10.2014)

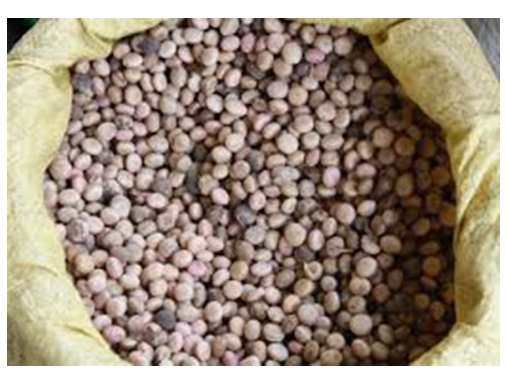

Fig. 10 Strychnos potatorum (clearing nut) seeds (Clearing nut, 31.10.2014)

Membrane based treatment methods In these methods, filtration occurs across a semi-permeable membrane due to gravity or a difference in pressure, osmotic potential, temperature or electric potential (Mulder 2000). Depending on the pore size, microfiltration $(0.1-1 \mu \mathrm{m})$ can retain only bacteria, ultrafiltration $(0.005-0.1 \mu \mathrm{m})$ can remove both bacteria and viruses, nanofiltration $(0.5-5 \mathrm{~nm})$ cannot retain salts, while reverse osmosis $(0.15-0.5 \mathrm{~nm})$ can even filter out salts (Fig. 12) (Peter-Varbanets et al. 2009) (Fig. 11).

Paper, fabric and fibre filters Considering the pore size of paper and fabric filters, only pathogens like Vibrio cholera can be filtered to a extent of 95-99\% (Sobsey 2002). Those made with multiple layers of polyester or nylon could remove cyclops and zooplankton (Agrawal and Bhalwar 2009). Up to 6 LRV of Escherichia coli and 3 LRV of Enterococcus faecalis, the removal is possible through bactericidal papers impregnated with silver nanoparticles due to inactivation offered by silver (Loo et al. 2012).

Microfiltration (MF) There are ceramic- and polymer-based microfiltration systems. In ceramic filters (Fig. 12), clay is mixed with burnout material to make porous ceramic filters of varied shapes with pore size of about $0.2-3.0 \mathrm{~mm}$ depending on the sophistication of manufacture (Sobsey et al. 2008). These ceramic filters could be locally made and coupled with silver impregnation to provide disinfection. The efficiency of removing bacterial and protozoan contaminants is significant (2-6 LRV and 4-6 LRV respectively); however, it is not so significant on viruses (0.5-4 LRV) (Sobsey et al. 2008). These filters can help in visible reduction in turbidity, however, needs to be cleaned and handled safely (Loo et al. 2012). Katadyn Mini, Potters for Peace pot-based clay filter (PFP, 28.10.2014) and Terafil filter (Terafil, 28.10.2014) are all a silver impregnated ceramic filters.

There are polymer-based microfiltration devices like FilterPen whose polymer size is about $0.15 \mathrm{~mm}$ with a surface area of $0.02 \mathrm{~m}^{2}$ (Peter-Varbanets et al. 2009).

Coated textile candle filter is another example for microfiltration. After regular prefiltration and activated carbon
Fig. 11 Different membrane purification regimes, the respective pore sizes and the particles that can be removed (PeterVarbanets et al. 2009)

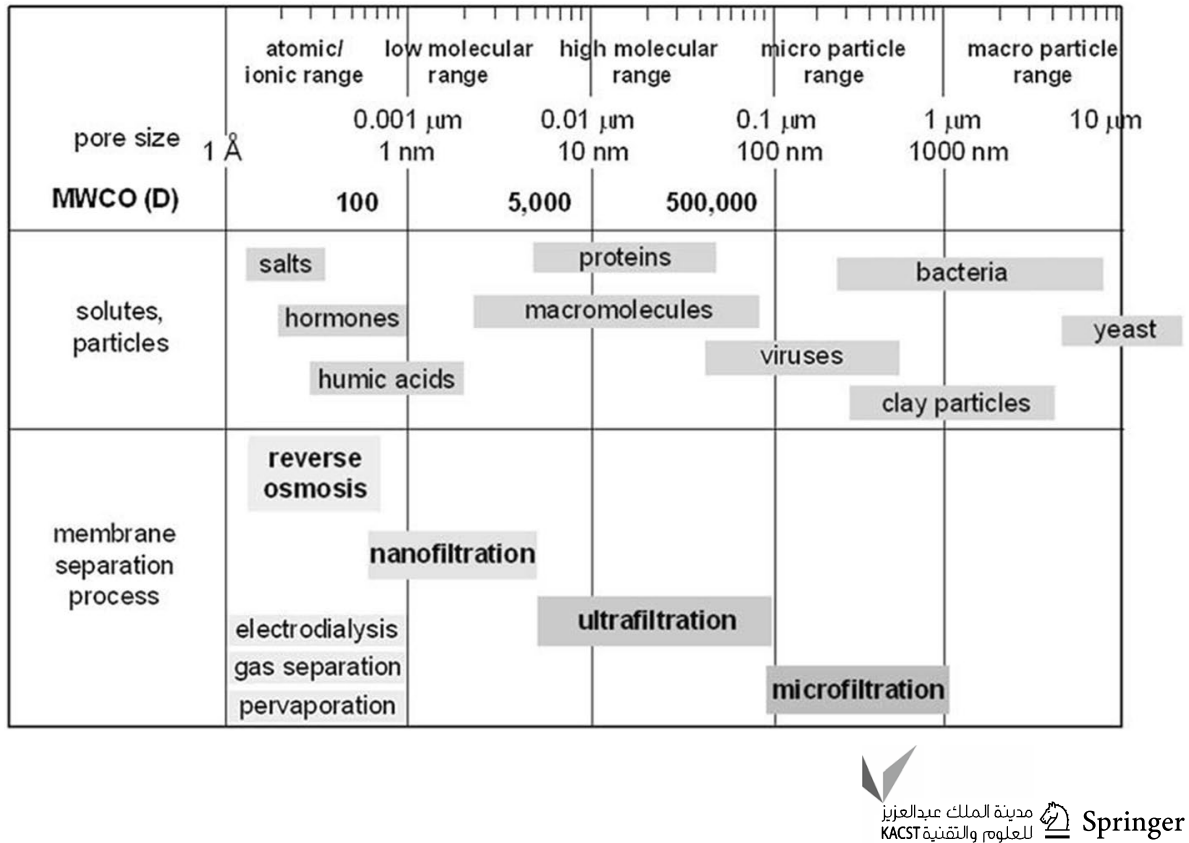



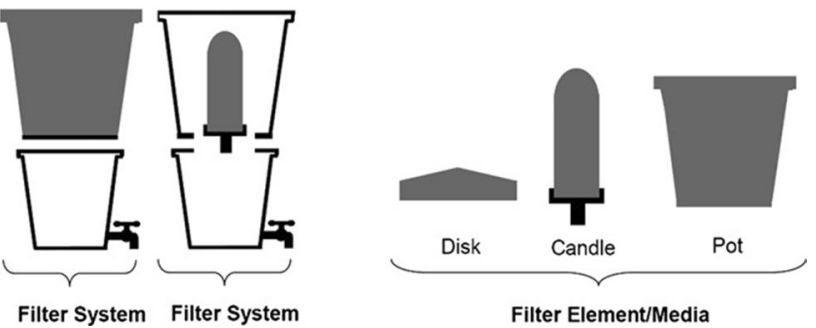

Fig. 12 Ceramic filter system and element in different forms (Simonis and Basson 2011)

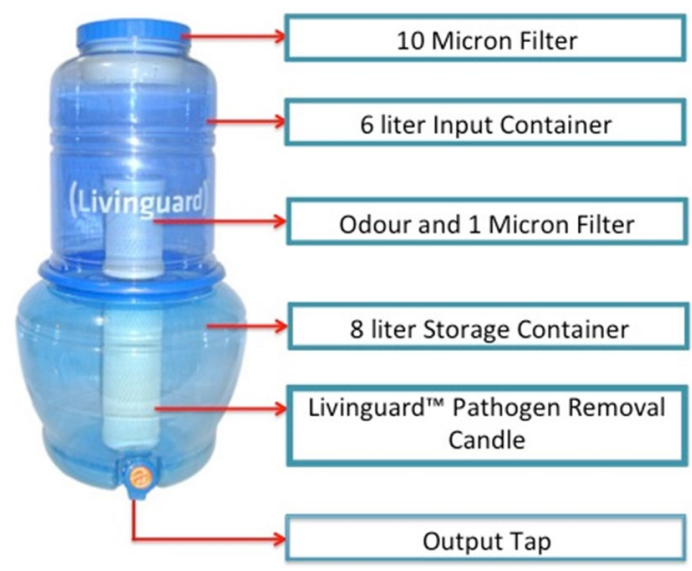

Fig. 13 Livinguard Rural Filter (Livinguard, 29.10.2014)

treatment, water is passed through a coated textile candle which claims to remove pathogens larger than $1 \mu \mathrm{m}$ and further ruptures microbes; however, the disinfection level is not specified. The whole setup is housed in PET containers (Fig. 13) (Livinguard, 29.10.2014).

Ultrafiltration (UF) and nanofiltration (NF) With much lesser pressure potential, ultrafiltration and nanofiltration techniques can ensure a complete microbial removal (PeterVarbanets et al. 2009). Although inlet water quality does not significantly affect the performance, periodical backwashing is required to prevent fouling. Some of the popular devices are Lifestraw (Lifestraw, 28.10.2014) (Fig. 14), wherein purified water is sucked from a vessel containing impure water (Loo et al. 2012). Another product named Lifesaver bottle (Fig. 15) claims to achieve 7.5 LRV against bacteria and $5 \mathrm{LRV}$ against viruses and treats about $4000 \mathrm{~L}$ of water (Lifesaver, 28.10.2014).

Pedal-operated UF purifiers have also been attempted like He (2009), Saini et al. (2013) (Fig. 16) and BARC (28.10.2014) where pressure of 4 bar generated through pedalling motion can accelerate discharge rate to about 36 L/hour (Saini et al. 2013). These systems greatly help in

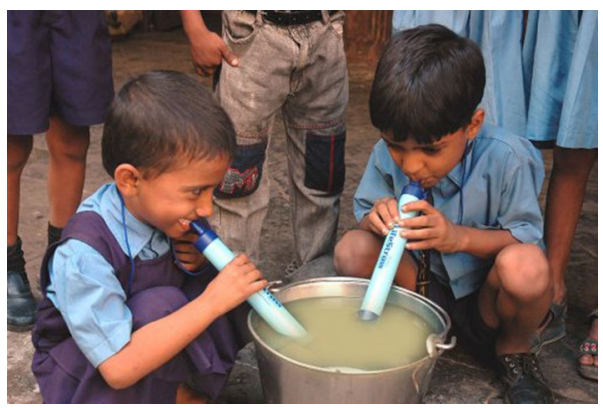

Fig. 14 Lifestraw in operation (Lifestraw in use, 31.10.2014)

Fig. 15 Lifesaver bottle (Lifesaver, 28.10.2014)

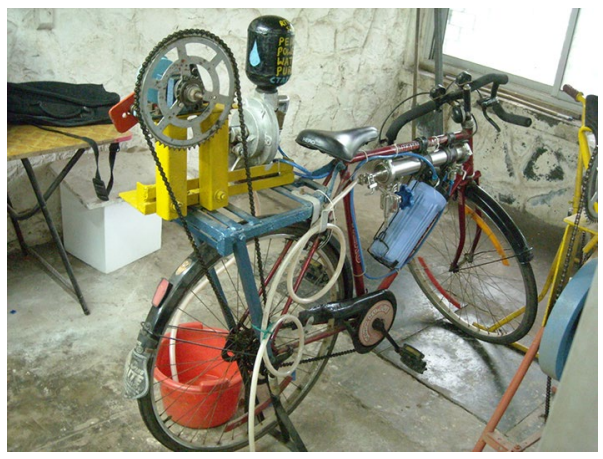

Fig. 16 Pedal powered UF system. Photo: Ramprasad V

improving the visibility of water by reducing turbidity (44.7 NTU to $0.267 \mathrm{NTU}$ ) and TDS along with microbial (total coliform count from $300 \mathrm{cfu} / 100 \mathrm{~mL}$ to $<1 \mathrm{cfu} / 100 \mathrm{~mL})(\mathrm{He}$ 2009).

There are modular variants of UF purifiers which are suitable for community scale like SkyHydrant, Lifestraw Family and also mobile variants like Jaldoot and Perferctor E (Loo et al. 2012; Peter-Varbanets et al. 2009).

Several stationary household UF purifiers are available like Moselle (Fig. 17), Jaltara (Fig. 18) and Waterife Little Star Gold (Moselle, 29.10.2014; Jaltara, 29.10.2014; Waterlife, 29.10.2014).

There is a unique experiment with plant xylem-based ultrafiltration. Bacteria up to $3 \mathrm{LRV}$ can get filtered out with sapwood (predominantly xylem) of trees like pine which is easily available, inexpensive, biodegradable and suitable for 
Fig. 17 Moselle purifier (Moselle, 29.10.2014)

Fig. 18 Jaltara filter (Jaltara, 29.10.2014)

Fig. 19 Preparation of the plant xylem purifier (Boutilier et al. 2014)

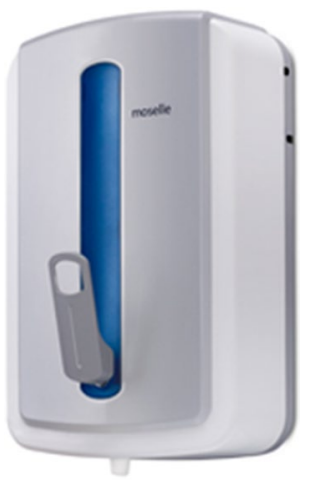

can be mounted on vehicles to make them mobile (PeterVarbanets et al. 2009).

Most RO purifiers are integrated water purifiers with methods such as microfiltration, ultrafiltration and ultraviolet treatment in conjunction with reverse osmosis based water filtration.

Forward osmosis (FO) In forward osmosis, a bag (e.g. Hydro Pack) made of semi-permeable membrane is filled with concentrated sugar solution and then dipped in impure water (HTI, 29.10.2014). Due to the osmotic potential, water enters the pouch and contaminants get trapped outside the bag (Fig. 21). The diluted sweet water packed with nutrients and minerals can be consumed directly (Peter-Varbanets et al. 2009). However, this method is suitable for individuals during emergencies, considering its high cost and low yield.

Biosand filter A biosand filter (BSF) consists of a container packed with sand where a biologically active layer (schmutzdecke) is allowed to develop on the top surface (Fig. 22) which restricts the passage of bacteria by around 2

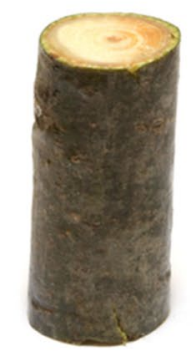

cut branch

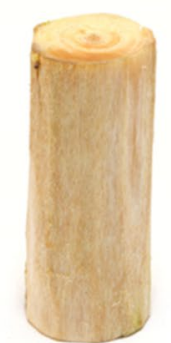

peel off bark

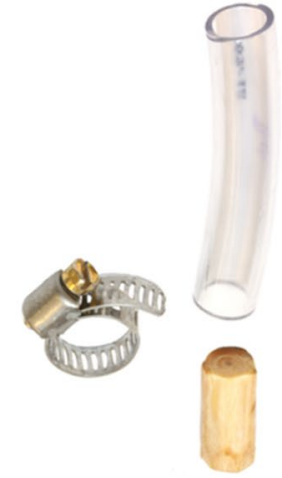

fasten into tube

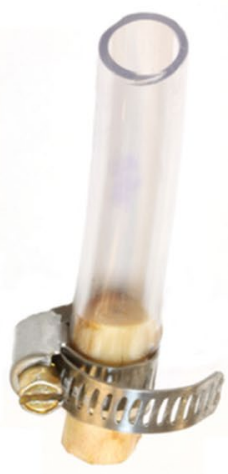

xylem filter resource-constrained environments (Boutilier et al. 2014). A small branch of a pine tree is peeled and then inserted into a tube and clamped to make the filter (Fig. 19). Achieving high flow rates is difficult; however, a volume of $3 \mathrm{~cm}^{3}$ of sapwood can meet the needs of an individual (Boutilier et al. 2014).

\section{Biopolymer-reinforced synthetic granular nanocomposites}

Reverse osmosis (RO) RO with pore size of $<1 \mathrm{~nm}$ and high water pressure filters out all types of pathogens and waterborne impurities (Fig. 20) (Loo et al. 2012). To avoid RO membranes getting fouled, prefiltration such as sedimentation, microfiltration and activated carbon filters (also in post-filtration) are adopted. RO-based water purifiers are generally expensive. RO systems can be coupled with photo-voltaic systems to power them (Loo et al. 2012) and
Fig. 20 Reverse Osmosis Purifier (Kent RO, 31.10.2014)

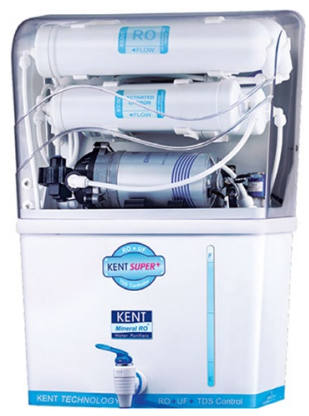

LRV and protozoa by more than $3 \mathrm{LRV}$ and viruses by about 1 LRV (Sobsey 2002; Peter-Varbanets et al. 2009). BSF can remove $95 \%$ turbidity and gives a discharge of about $20 \mathrm{~L} /$ hour (Peter-Varbanets et al. 2009). A diffuser plate is placed on bio-layer to avoid disturbance of schmutzdecke and the 
Fig. 21 Forward Osmosis X-Pack (HTI, 20.11.2019)

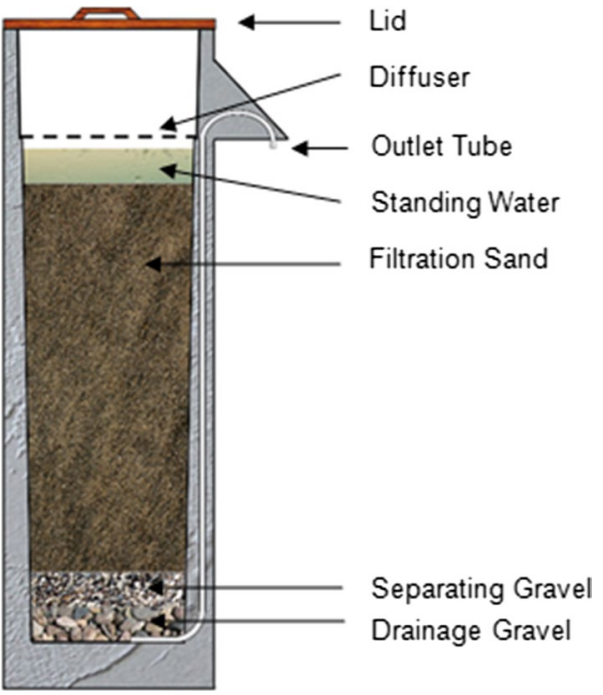

Fig. 22 Cross section of a biosand filter (Biosand, 31.10.2014)

user just pours in water on top of the diffuser plate and collects filtered water from the outlet. NEERI-Zar developed by CSIR-National Environmental Engineering Research Institute (NEERI) is also a type of modified sand-based water filter (NEERI, 22.04.2017).

\section{Integrated water purification}

Considering the advantages and limitations of different water treatment methods, some of the household water purifiers combine multiple types of water treatment techniques. For example, the RO systems generally are supported by microfiltration, ultrafiltration and ultraviolet treatment techniques. There are also some mobile purification units comprising of multiple methods of water treatment like micro-hydraulic mobile water treatment plant (MHMWTP) which have been developed. MHMWTP incorporates chlorination, sedimentation, filtration and optional granular-activated carbon (GAC) treatment (Garsadi et al. 2009). Similar mobile system is Jaldoot (Fig. 23) which involves multiple treatment mechanisms ranging from pressurised sand filtration, GAC module,

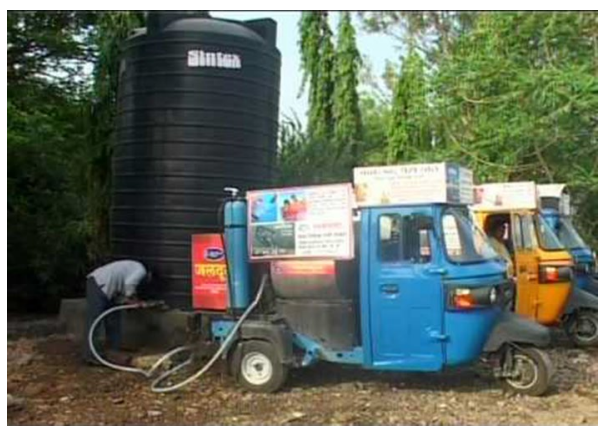

Fig. 23 Jaldoot mobile purifier (Jaldoot, 29.10.2014)

microfiltration and ultrafiltration all integrated into one unit on a three-wheeler. This unit is capable of delivering $1500 \mathrm{~L}$ every hour (Jaldoot, 29.10.2014).

Another example of integrated water purification is microfiltration coupled with biopolymer-reinforced synthetic granular nanocomposites which release silver ions in water offer arsenic and microbiological disinfection at a low cost (Sankar et al. 2013). The system has a discharge rate of 10 L/hour and purifies $3600 \mathrm{~L}$ of water (Sankar et al. 2013) (Fig. 24).

\section{Review of purifier alternatives}

\section{Attributes selected for review}

The reference for different attributes which evaluate the purifiers was primarily followed as in Peter-Varbanets et al. 2009 and Loo et al. 2012. However, the list of attributes and their priority (Table 1) was selected based on their relevance to a low-income rural context. Specifically, the context is that of a coastal rural area in a developing country like India, wherein there were no major chemical contaminants identified in the decentralised water sources, mostly open wells.

The finalised list of attributes (and the reference for scoring) is selected for review as follows.

i. Sustainability (Peter-Varbanets et al. 2009)

ii. Purification performance (Peter-Varbanets et al. 2009)

iii. Rate of production (Peter-Varbanets et al. 2009)

iv. Maintenance (Peter-Varbanets et al. 2009)

v. Energy requirement or dependence on utilities (PeterVarbanets et al. 2009)

vi. Ease of use (Peter-Varbanets et al. 2009)

vii. Portability/ease of deployment (Aggregated from multiple sources including local references, primarily Loo et al. 2012)

viii. Supply chain requirement (Loo et al. 2012) 
Fig. 24 Schematic diagram of the purifier prototype (A) and its actual photograph (B) (Sankar et al. 2013)
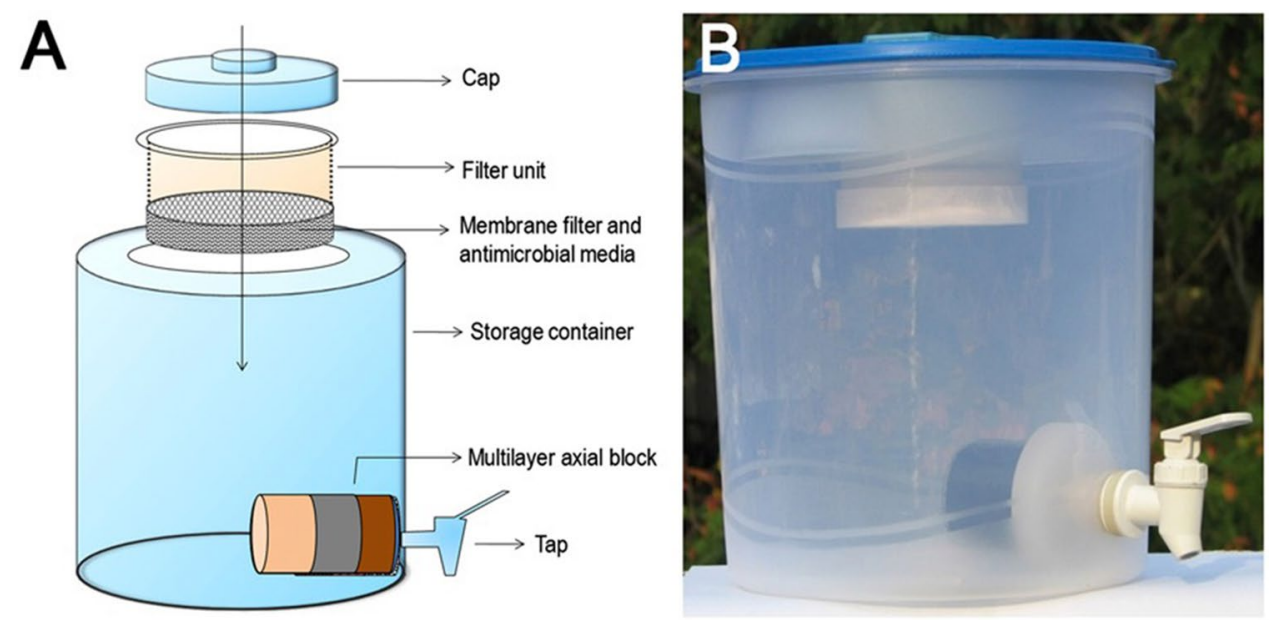

Table 1 Priority matrix for each attribute

\begin{tabular}{ll}
\hline Technology/method/product & Priority \\
\hline Purification performance & 6 \\
Cost (Rs/L) & 6 \\
Rate of production L/hour & 6 \\
Ease of use & 4 \\
Maintenance & 4 \\
Energy requirement or dependence on utilities & 4 \\
Portability and ease of deployment & 2 \\
Social acceptability & 2 \\
Sustainability & 2 \\
Supply chain requirement & 2
\end{tabular}

ix. Cost (in Rs/L) (Lifetime and investment adjusted) (Aggregated from multiple sources including local references, primarily Peter-Varbanets et al. 2009)

x. Social acceptability (Peter-Varbanets et al. 2009)

The above attributes can further be broadly classified based on the categories proposed by Pagsuyoin et al. (2015) into technological performance, environmental sustainability, economic viability and social acceptability. This is a simpler way of integrating the attributes for a given context. Based on the categorisation, the following attributes: purification performance, rate of production, maintenance, energy requirement or dependence on utilities, ease of use, portability/ease of deployment and supply chain requirement will mostly get categorised under technological performance. Further, sustainability, cost and social acceptability would get categorised into environmental sustainability, financial viability and social acceptability, respectively.

However, it is to be noted that this broad categorisation of attributes is simplistic and not exactly as proposed in Pagsuyoin et al. (2015). Since the scores for different attributes selected were mostly from Peter-Varbanets et al. (2009), Loo et al. (2012) and other sources, an independent methodology for review, hve been adopted.

\section{Alternatives selected for review}

The classification of water purification techniques in "Classification of water purifiers" section represents an overall academic approach to illustrate wide spectrum of options possible with a special focus towards possibilities in the context of decentralised water sources as in rural coastal areas in developing countries like India. However, to adopt a more practical approach for identifying the appropriate water purifier for a given scenario, the water purifiers for which sufficient information from primary sources (field observations) and secondary sources (literature review) was available were chosen for review. A thorough literature review was undertaken from multiple references, but primarily from Peter-Varbanets et al. 2009 and Loo et al. 2012. The purifiers for which sufficient information for comparison against all attributes was chosen were as follows:

i. Household boiling

ii. Solar stills

iii. Solar disinfection

iv. UV-based purifiers

v. Chlorination

vi. Combined coagulation-disinfection (PuR sachet)

vii. Biosand Filter

viii. Household Ceramic Filters

ix. Portable UF (Lifesaver bottle)

x. Bicycle powered UF

xi. Small-scale Reverse Osmosis

xii. FO reusable filter pouch 


\section{Analysis of review of alternatives}

This section presents a detailed comparison based on preferential scores assigned for each purification method based on its performance against a particular attribute. The attributes have been accorded priority considering a lowincome rural household as the case in focus. Several visits to Ransai, Vavoshi and Shiroshi villages on Pen-Khopoli road in Raigad District of Maharashtra State in India were undertaken with support from a social organisation named Rural Communes. Similarly, several visits to villages near Ganeshpuri in Palghar district of Maharashtra State in India were undertaken with support from a social organisation named Shree Nityananda Education Trust (SNET). Based on extensive visits to these villages, observation of water sources, feedback from villagers and discussions with teams of social organisations, the attributes used to rate the purifiers were accorded priority. Physical filtration of turbidity and removal of pathogens turned out to be some of the key needs of the villages. This formed the specifics of the context of the review methodology: a rural setup in the coastal area in a developing country like India wherein open wells are the primary water sources and the primary concerns of water quality are mostly physical (turbidity) and biological (microbial contamination). No specific chemical contamination has been focused in the review as no such major issue was identified in the field area under consideration.

The purification methods have been assigned scores based on their performance again each attribute out of a total score of 3. Finally, the total score of each purification method is calculated by summing up the product of the score against a particular attribute and the attribute's priority (Table 2).

\section{Description of score rating of purifiers against each attribute}

(i) Purification performance against pathogens

Purification performance is microbial removal efficiency against pathogens. This attribute primarily considers performance in terms of effectiveness in the removal of bacteria. This was observed as one of the key needs in the villages surveyed apart from physical treatment in terms of turbidity. While turbidity does not have immediate adverse impact over the health of the people, the removal of pathogens is one of the critical needs; hence, this attribute has been assigned the highest priority of 6 out of 6 (Table 1). Apart from boiling, coagulation-disinfection, RO, FO, UV and UF, there seem to be no "foolproof" method of microbial disinfection; hence, these have been assigned a score of 3 out of 3 . All of these are expensive except boiling when firewood is easily available and hence probably indicates the huge dependency of rural areas on boiling. The remaining purification techniques are assigned a score of 2 out of 3 .

\section{(ii) Cost Rs/L (lifetime and investment adjusted)}

In the villages which were considered, cost is a crucial consideration in the adoption of any water purifier because population is mostly composed of low-income households. Hence, once again the highest priority of 6 out of 6 has been assigned to the cost attribute (Table 1). Each purifier has a time limit within which the purifier's operational efficiency is acceptable. To take into account the investment and operational costs of the purifier over its lifetime, cost is calculated for every liter of water purifier based on the information of lifetime of the purifier available through the literature or through field-based observation. The ratio of purifier's investment cost to the volume purified over its lifetime is summed up with the operational cost over the purifier's lifetime in consistent units and presented as a single attribute as cost in Rs/L. (This review assumes a conversion rate of 1 US\$ = INR Rs.60.) In this regard, sand/ceramic-based and chlorination-based purification is the cheapest (score 3 out of 3), while UF, solar stills, RO and FO are quite expensive (score 1 out of 3 ). The remaining purification methods have been assigned a score of 2 out of 3 .

\section{(iii) Rate of production}

This attribute implies the ability to cater to increased demands of water within a short period of time. Boiling, SODIS, chlorination and combined coagulation-disinfection can be scaled up and down to meet the flexible demands, methods like UV, household UF, bicycle UF and RO have production rates of $>10 \mathrm{~L} /$ hour; hence, these have been assigned a score of 3 out of 3 . Solar distillation and forward osmosis have $<0.1 \mathrm{~L} /$ hour (score 1 out of 3 ), while purifiers like Tata Swach, HUL Pureit, ceramic, biosand filter, Terafil and Lifestraw have discharge rates which are in between 0.1 and $10 \mathrm{~L} /$ hour (score 2 out of 3 ). If the rate of production is too low, it often renders the purifier unusable; hence, this attribute is also assigned a high priority of 6 out of 6 (Table 1).

\section{(iv) Ease of use}

If a purifier is convenient to handle and use, there are higher chances of its continued usage. Based on the field observations, it was inferred that ease of use for the community matters quite heavily in terms of purifier's continued usage. Hence, this is assigned a priority of 4 out of 6 (Table 1). Referring to Peter-Varbanets et al. (2009), some qualitative scores have been assigned as follows. A score of 3 (out of 3 )/ ++ is given for most purifiers which can be handled easily and which require only filling of feed water and collection of purified water. A score of 2 (out of 3$) /+$ is allocated if any extra effort is required 
Table 2 Point-of use water purifiers rated against various attributes (which are prioritised) and segregated depending on the scores

\begin{tabular}{|c|c|c|c|c|c|c|c|c|c|c|c|}
\hline $\begin{array}{l}\text { Technolo } \\
\text { gy/meth } \\
\text { od }\end{array}$ & $\begin{array}{l}\text { Purification } \\
\text { performance }\end{array}$ & $\begin{array}{l}\text { Cost Score } \\
\text { and (Rs/L) }\end{array}$ & $\begin{array}{c}\text { Rate of } \\
\text { production } \\
\text { L/hour }\end{array}$ & Ease of use & $\begin{array}{c}\text { Maintenan } \\
\text { ce }\end{array}$ & $\begin{array}{c}\text { Energy } \\
\text { requireme } \\
\text { nt or } \\
\text { dependenc } \\
\text { e on } \\
\text { utilities }\end{array}$ & $\begin{array}{c}\text { Portability } \\
\text { and ease } \\
\text { of } \\
\text { deploymen } \\
t\end{array}$ & $\begin{array}{c}\text { Social } \\
\text { acceptabi } \\
\text { lity }\end{array}$ & $\begin{array}{c}\text { Sustainabil } \\
\text { ity }\end{array}$ & $\begin{array}{l}\text { Supply } \\
\text { chain } \\
\text { requirem } \\
\text { ent }\end{array}$ & $\begin{array}{l}\text { Total (Sum of } \\
\text { product of } \\
\text { score and } \\
\text { corresponding } \\
\text { priority) }\end{array}$ \\
\hline Boiling & 3 & $2(0.68)$ & 3 & 2 & 3 & 1 & 3 & 3 & 1 & 2 & 90 \\
\hline $\begin{array}{l}\text { Solar } \\
\text { stills }\end{array}$ & 3 & $1(3.27)$ & 1 & 2 & 3 & 2 & 2 & 1 & 3 & 2 & 74 \\
\hline $\begin{array}{c}\text { Solar } \\
\text { disinfecti } \\
\text { on }\end{array}$ & 2 & $2(0.17)$ & 3 & 2 & 3 & 2 & 3 & 1 & 3 & 2 & 88 \\
\hline $\begin{array}{c}\text { UV } \\
\text { disinfecti } \\
\text { on }\end{array}$ & 2 & $2(0.61)$ & 3 & 3 & 2 & 1 & 2 & 2 & 2 & 2 & 82 \\
\hline $\begin{array}{l}\text { Chlorinat } \\
\text { ion }\end{array}$ & 2 & $3(0.05)$ & 3 & 2 & 3 & 3 & 3 & 1 & 2 & 1 & 94 \\
\hline $\begin{array}{l}\text { Combine } \\
\text { d } \\
\text { coagulati } \\
\text { on and } \\
\text { disinfecti } \\
\text { on }\end{array}$ & 3 & $2(0.21)$ & 3 & 2 & 3 & 3 & 3 & 1 & 2 & 1 & 94 \\
\hline $\begin{array}{l}\text { Biosand } \\
\text { Filter }\end{array}$ & 2 & $3(0.04)$ & 2 & 3 & 3 & 3 & 2 & 2 & 3 & 3 & 98 \\
\hline $\begin{array}{l}\text { Househo } \\
\text { Id } \\
\text { Ceramic } \\
\text { Filters }\end{array}$ & 2 & $3(0.04)$ & 2 & 3 & 2 & 3 & 2 & 2 & 3 & 2 & 92 \\
\hline $\begin{array}{l}\text { Househo } \\
\text { Id UF }\end{array}$ & 3 & $1(2.55)$ & 3 & 3 & 1 & 2 & 3 & 2 & 1 & 2 & 82 \\
\hline $\begin{array}{l}\text { Bicycle } \\
\text { powered } \\
\text { UF }\end{array}$ & 3 & $1(2.1)$ & 3 & 2 & 1 & 2 & 2 & 1 & 2 & 2 & 76 \\
\hline $\begin{array}{c}\text { Small- } \\
\text { scale RO }\end{array}$ & 3 & $1(1.43)$ & 3 & 3 & 1 & 1 & 2 & 1 & 1 & 2 & 74 \\
\hline $\begin{array}{c}\text { FO } \\
\text { reusable } \\
\text { filter } \\
\text { pouch } \\
\end{array}$ & 3 & $1(240)$ & 1 & 3 & 2 & 3 & 3 & 2 & 1 & 1 & 76 \\
\hline \multirow{3}{*}{$\begin{array}{l}\text { Legend } \\
\text { for } \\
\text { colour } \\
\text { code and } \\
\text { score } \\
\text { assigned }\end{array}$} & ++ & $<0.1$ & $\begin{array}{c}<1 \\
\text { /Flexible }\end{array}$ & ++ & $\begin{array}{l}\text { No } \\
\text { replaceme } \\
\text { nt / } \\
\text { requireme } \\
\text { nt of } \\
\text { regular } \\
\text { supply }\end{array}$ & $\begin{array}{c}\text { Nil / } \\
\text { Gravity } \\
\text { /osmotic } \\
\text { potential / } \\
\text { tap } \\
\text { pressure / } \\
\text { mouth } \\
\text { suction }\end{array}$ & ++ & $\begin{array}{c}++/ \text { traditi } \\
\text { on }\end{array}$ & + & 5 & $90-100$ \\
\hline & + & $0.1-1$ & $1-100$ & + & $\begin{array}{c}\text { Inexpensiv } \\
\text { e module } \\
\text { replaceme } \\
\text { nt }\end{array}$ & $\begin{array}{l}\text { Mechanical } \\
\text { pumping }\end{array}$ & + & + & - & $2-4$ & $80-89$ \\
\hline & & $>1$ & $>100$ & & $\begin{array}{c}\text { Expensive } \\
\text { module } \\
\text { replaceme } \\
\text { nt }\end{array}$ & $\begin{array}{c}\text { Fuel / } \\
\text { electricity }\end{array}$ & & $\begin{array}{c}+/-/ \\
\text { pedalling } \\
\text { / taste } \\
\text { and oder } \\
\text { problem }\end{array}$ & - & 1 & 70-79 \\
\hline $\begin{array}{l}\text { Referenc } \\
\text { es }\end{array}$ & $\begin{array}{c}\text { Peter- } \\
\text { Varbanets et } \\
\text { al. (2009) }\end{array}$ & $\begin{array}{l}\text { Aggregated } \\
\text { from } \\
\text { multiple } \\
\text { sources, } \\
\text { primarily } \\
\text { Peter- } \\
\text { Varbanets } \\
\text { et al. } \\
\text { (2009) }\end{array}$ & $\begin{array}{l}\text { Peter- } \\
\text { Varbanets } \\
\text { et al. } \\
\text { (2009) }\end{array}$ & $\begin{array}{l}\text { Peter- } \\
\text { Varbanets } \\
\text { et al. } \\
\text { (2009) }\end{array}$ & $\begin{array}{l}\text { Peter- } \\
\text { Varbanets } \\
\text { et al. } \\
\text { (2009) }\end{array}$ & $\begin{array}{l}\text { Peter- } \\
\text { Varbanets } \\
\text { et al. } \\
\text { (2009) }\end{array}$ & $\begin{array}{l}\text { Aggregated } \\
\text { from } \\
\text { multiple } \\
\text { sources, } \\
\text { primarily } \\
\text { Loo et al. } \\
(2012)\end{array}$ & $\begin{array}{l}\text { Peter- } \\
\text { Varbanet } \\
\text { s et al. } \\
(2009)\end{array}$ & $\begin{array}{l}\text { Peter- } \\
\text { Varbanets } \\
\text { et al. } \\
\text { (2009) }\end{array}$ & $\begin{array}{l}\text { Loo et al. } \\
\text { (2012) }\end{array}$ & \\
\hline
\end{tabular}

like chlorination and combined coagulation-disinfection demand stirring, boiling requires heating, SODIS and solar distillation require effort to place the purifiers under the sun and bicycle UF requires pedalling. (v) Maintenance

It is often seen in the field areas that once a water purifier is handed over to a rural community, its proper 
maintenance is often neglected. Improper maintenance may cause the purifier to malfunction, and hence, maintenance is accorded a priority of 4 out of 6 (Table 1). Maintenance in some form is required for all purifiers while the most common being cleaning water holding containers. Other maintenance operations include back flushing of membrane filters, removing depositions on candle filters and scraping off the top layer of sand in biosand filters. There is replacement of chemicals in chlorination, combined coagulation-disinfection and FO, while there is replacement of cartridges/membranes in ceramic microfiltration, household UF, bicycle UF and RO methods. Boiling, solar stills, SODIS, BSF, chlorination and combined coagulation and disinfection require the basic amount of maintenance and have been given score 3 out of 3 as the purifier would not severely malfunction in the absence of maintenance. Ceramic filters, UV and FO pouches require inexpensive replacements and hence have been given a score of 2 out of 3. RO and UF hugely depend on expensive module replacements and hence have been given a score of 1 out of 3 .

\section{(vi) Energy requirement or dependence on utilities}

Different purification methods are dependent on different energy utilities, and this attribute needs to be considered for rural areas. Since it is observed that energy constraints are often prevalent in rural settings, this attribute is accorded a priority of 4 out of 6 (Table 1). Boiling requires fuel; UV and RO depended on electricity and hence have been assigned a score of 1 out of 3 . UF systems require mechanical effort and SODIS \& household stills depend on sufficient solar radiation and have been given a score of 2 (out of 3). The other methods do not need any external energy or depend on gravity and osmotic potential for their energy requirements and hence have a score of 3 .

\section{(vii) Ease of deployment}

The ease of deployment is quite relevant in remote circumstances. Since ease of deployment plays a major role in handling of the purifier during deployment as well as shifting which could be common in a rural setting, this is assigned a priority of 2 out of 6 (Table 1). Purification methods which can be easily deployed and used (boiling, SODIS, chlorination, CCD, household UF, FO) have been given a score of 3 out of 3 . However, if the purifier's sophisticated make-up hampers its rugged use, then a value of 2 out of 3 is assigned. For example, biosand filter being bulky and taking considerably long start-up time and purifiers like solar stills, UV, RO and ceramic filters being delicate and prone to damage during handling/ transporting.

\section{(i) Sociocultural acceptability}

In the selected villages for the study, it appeared that sociocultural acceptability appeared to be an important consideration which cannot be neglected in terms of adoption of purifiers. Social acceptability has been assigned a priority of 2 out of 6 (Table 1). Boiling being the only traditionally practised method is given a score of 3 (out of 2). Most purifiers which were accepted when deployed (ceramic, UV, biosand, household UF and FO) have been assigned a 2 marks out of 3. Although chlorination and combined coagulation-disinfection have been in use for quite some time, they produce bad taste and odour. Some purifiers like SODIS have not been readily accepted even after deployment; further, bicycle-based UF requires some investment and pedalling effort and RO requires higher investments and electricity and hence have not been fully accepted. These methods have been assigned a score of 1 (out of 3 ).

\section{(ii) Environmental sustainability}

Environmental sustainability is difficult to quantify and can be sometimes subjective; however, usage of any purifier has environmental implications which is quite important to consider. Referring to Peter-Varbanets et al. (2009), some qualitative indications have been assigned as follows. Purification methods like boiling, household UF, RO and FO which are either energy intensive (electricity or firewood) or incorporate advanced systems and resources for short-term needs or have high rejection rates are assigned 1 out of 3 . SODIS, solar distillation, BSF and household ceramic filter have been assigned 3 marks (out of 3 ) because they are either made from locally available materials with limited application of chemicals and are less dependent on non-renewable energy. Chlorination, combined flocculation-disinfection, UV and bicycle-operated UF have been classified with 2 marks (out of 3) due to their dependence either on chemical usage or due to the incorporation of exhaustible purifier components which cannot be locally sourced because of the use of sophisticated technology. Environmental sustainability has been accorded a priority of 2 out of 6 (Table 1).

(iii) Supply chain requirement

The selected areas of study are quite remote, wherein supply chain needs to be worked out from the nearby cities to nearby prominent villages/towns. Even if the water purifier is deployed once, unless the replacements and accessories are made available, the usage of purifiers in the long run may come to an end. Since supply chain is gradually improving, it has been assigned a priority of 2 out of 6 (Table 1). Biosand filters are assigned a score of 3 (out of 3 ) due to non-requirement of replaceables. Boiling, solar-based techniques, UV, ceramic filters, UF and RO need occasional supply in the form of fuel or replacement of a few accessories; hence, these have been given a score of 2 (out of 3). However, chlorination and FO-based techniques need strong supply chain 
network due to requirement of frequent replenishment and are given a score of 1 (out of 3 ).

\section{Concluding remarks}

This study adopts both academic and practical approaches towards water purifiers. The classification and description of water treatment alternatives are based on the operating technologies adopted for purification, so as to present a broad spectrum of possibilities. However, the review is based on the practical approach of evaluating water purifiers in the manner they can be used in the selected context. As presented in the review, there are a lot of alternatives available for a family-level water treatment even for a low-income household with decentralised water source in a developing country. The selection process of the optimal type of purifier for a given setting requires an assessment of different purification methods against several relevant attributes. However, the conditions in different places within a diverse country could be different. Based on the observations in the coastal region of Maharashtra in India, the attributes have been prioritised. The purifiers are then compared based on data available from primary and secondary sources. The review as an example indicates some of the purifiers suitable to the chosen scenario. Going further, this methodology can be used as a template to identify the best possible water purification technique relevant to the given scenario by tweaking the priority assigned to each attribute in the review based on the circumstance.

The viewpoint of this review was to classify, describe and review various household point-of-use water purifier based on prioritised attributes according to a local context. Some of the observations made through this review is as follows.

- This is a wide spectrum of alternatives available in terms of technologies and water purifying devices.

- Nowadays, membrane-based technologies in the realm of physical removal methods have a widespread adoption.

- Based on the review, it can be inferred that no single purifier meets the mark in terms of all the attributes.

- However, considering the summation of the product of the scores of the purifiers $(>90)$, it can be observed that boiling, biosand, ceramic and chlorination-based techniques seem to score the highest considering the priorities.

- The above inference tends to match with the field observations in the selected villages, wherein these purifiers were used or deployed or seem agreeable to the people of the villages.

- Based on field observation, it has been found that purifiers with low energy demands, those which are easy-to- use and handle and which can cater to flexible quantum of water requirements tend to have a higher adoption.

- No matter what purification techniques are considered, certain attributes like purification performance will always be an important parameter for consideration.

- It could probably be generalised that it would be hard to find a single water purifier which meets all the requirements as per all attributes in all contexts. Therefore, considering the specific needs and circumstances of the prevailing context, an optimum purifier could to be selected considering its advantages and limitations.

- There is a huge scope for working on further fine-tuning low-cost, environmentally sustainable, easy-to-use water purifiers offering effective water treatment.

Point-of-use purifiers are especially suitable for water sourced from decentralised sources like tube wells, open wells, ponds and rain water harvesting tanks. It is observed that point-of-use purifiers are being increasingly used in developing countries irrespective of the water quality supplied by public utilities. This is so, because there is a high chance of contamination of water which is supplied even through centralised systems in areas like congested areas. PoU purifiers are also suitable for deployment during emergencies. Another observation noted is that most purifiers incorporate integrated treatment combing multiple purification methods, as generally observed in the case of household RO purifiers which generally incorporate micro-/nanofiltration and UV treatment.

It is, however, observed that household RO water purifiers are used as a common remedy for any type of water treatment need. RO purifiers are not only expensive and environmentally unsustainable (due to huge energy consumption and large release of discharge water) but may not be considered advisable for regular consumption (in case of routine water issues which are not very serious). It is in such a scenario that this review comes in hand, wherein the appropriate water purifier suitable to the relevant issue of water quality can be selected.

The future scope of this work could involve deeper market survey to consider more recent actual prices (apart from literature references) as these keep changing rapidly. Considering user perspective through surveys could also help in understanding the perceptions in terms of ease of use and sociocultural acceptability of the purifiers. This study does not include the ability of water purifiers to treat special chemical contaminants like arsenic, fluoride, etc.

This study considers an independent methodology for review of water purifiers based on references primarily from Peter-Varbanets et al. (2009) and Loo et al. (2012). However, there is further scope for undertaking a review based on a simpler way of integration of attributes could be as proposed 
in Pagsuyoin et al. (2015), which takes into account most of the attributes considered in this review.

Selecting a particular purifier depends on the several factors, among which some are changing needs, context of usage, development of technology, ease of use and market reach, etc. Amidst so many variables, identifying the appropriate purifier, is a challenge. However, as an example from this review, one can adopt a general methodology which could be used to identify the suitable water purifier for a given context. As described in earlier sections, the selection process first involves assigning the relevant priority to each attribute considering the prevailing situations in the given context. Secondly, rating all the water purifiers could possibly be adopted in the given context against each parameter. Finally, calculating the product of the score and the priority of the corresponding attribute identify the total score for each purifier. The appropriate water purifier is the one which has the highest score when calculated according this template.

Acknowledgements This work was carried out as part of a seminar coursework in IIT Bombay. The authors are grateful to the academic resources received from IIT Bombay, which contributed to most of this work. The authors also acknowledge the financial support of Tata Centre for Technology and Design (TCTD) for the project on Development of Clay based Water Purifier considering Local Needs, Skills and Materials, whose component was this study.

Funding This study was conducted as part of a project supported by the Tata Centre for Technology and Design, Indian Institute of Technology Bombay.

\section{Compliance with ethical standards}

Conflict of interest The authors declare that they have no conflict of interest.

Open Access This article is licensed under a Creative Commons Attribution 4.0 International License, which permits use, sharing, adaptation, distribution and reproduction in any medium or format, as long as you give appropriate credit to the original author(s) and the source, provide a link to the Creative Commons licence, and indicate if changes were made. The images or other third party material in this article are included in the article's Creative Commons licence, unless indicated otherwise in a credit line to the material. If material is not included in the article's Creative Commons licence and your intended use is not permitted by statutory regulation or exceeds the permitted use, you will need to obtain permission directly from the copyright holder. To view a copy of this licence, visit http://creativecommons.org/licenses/by/4.0/.

\section{References}

Agrawal VK, Bhalwar R (2009) Household water purification: low-cost interventions. Med J Armed Forces India 65:260-263

Aquaguard (28.10.2014) Aquaguard Compact, Eureka Forbes http:// www.eurekaforbes.com/Product/Water-Purifiers/Aquaguard/ Essential/Aquaguard-Compact?pid $=10$
BARC (28.10.2014) Bicycle mounted water purification (RO/UF) unit driven by hybrid power system. Bhabha Atomic Research Centre. http://www.barc.gov.in/technologies/bicycle/bicycle_br.html

Berg PA (2010) A new water treatment product for the urban poor in the developing world. In: World Environmental and Water Resources Congress 2010: Challenges of Change ASCE, 2010-2025

Biosand (31.10.2014) Biosand filter. Centre for Affordable Water and Sanitation Technology. http://biosandfilters.info/

Boutilier MSH, Lee J, Chambers V, Venkatesh V, Karnik R (2014) Water filtration using plant xylem. PLoS ONE 9(2):e89934

CDC (28.10.2014) The safe water system, centers for disease control and prevention http://www.cdc.gov

Clearing nut (31.10.2014) Strychnos potatorum (clearing nut) seeds. Foundation for Revitalization of Local Health Traditions. http:// envis.frlht.org/raw-drug.php?show $=220$

Flendrig LM, Shah B, Subrahmaniam N, Ramakrishnan V (2009) Low cost thermoformed solar still water purifier for D\&E countries. Phys Chem Earth 34:50-54

Gadgil A (1998) Drinking water in developing countries. Annu Rev Energy Environ 23:253-286

Garsadi R, Salim HT, Soekarno I, Doppenberg AFJ, Verberk JQJC (2009) Operational experience with a micro hydraulic mobile water treatment plant in Indonesia after the "Tsunami of 2004". Desalination 248:91-98

Gupta SK, Islam MS, Johnston R, Ram PK, Luby SP (2008) The Chulli water purifier: acceptability and effectiveness of an innovative strategy for household water treatment in Bangladesh. Am J Trop Med Hyg 78:979-984

He Y (2009) Transportable membrane system produces drinking water. Membr Technol 2009:8-9

HTI (20.11.2019) HTI products. Hydration Technology Innovations http://www.htiwater.com/divisions/humanitarian/products.html

Islam MF, Johnston RB (2006) Household pasteurization of drinkingwater: the Chulli water-treatment system. J Health Popul Nutr $24: 356-362$

Jaldoot (29.10.2014) Jaldoot - the water messenger'. Swayamsiddha Mahila Utkarsha Foundation http://www.jaldoot.org/

Jaltara (29.10.2014) Jaltara: BARC Technology Water Purifier. Sonadka http://www.sonadka.net/barc-technology-water-purifier.html

Kang G, Roy S, Balraj V (2006) Appropriate technology for rural India-solar decontamination of water for emergency settings and small communities. Trans R Soc Trop Med Hyg 100:863-866

Kent RO (31.10.2014) Reverse osmosis purifier. Kent Mineral RO Water Purifiers. Source: http://www.kent.co.in/Products-Water -Purifiers-RO

Khan MU, Khan MR, Hossain B, Ahmed QS (1984) Alum potash in water to prevent cholera. Lancet 8410:1032

Lantagne DS, Clasen T (2009) Point of use water treatment in emergency response. London School of Hygience and Tropical Medicine, London

Lifesaver (28.10.2014) LIFESAVER 4000UF Bottle. Lifesaver Systems Ltd. http://www.lifesaversystems.com/

Lifestraw (28.10.2014) Lifestraw Products. Vestergaard. http://www. buylifestraw.com/

Lifestraw in use (31.10.2014) Lifestraw in operation. www.amazo n.com. http://ecx.images-amazon.com/images/I/519Op $7 \mathrm{kmt} 4$ L.jpg

Livinguard (29.10.2014) Livinguard Rural Filter-14 Litre Capacity. Livinguard Technologies Pvt. Ltd. http://www.livinguard.com/ water/water-products

Loo S, Fane AG, Krantz WB, Lim T (2012) Emergency water supply: a review of potential technologies and selection criteria. Water Res 46:3125-3151

Moringa Tree (30.10.2014) Moringa Tree, Wikipedia; http://en.wikip edia.org/wiki/Moringa_oleifera 
Moselle (29.10.2014) Moselle water purifier. Membrane Filters India Pvt. Ltd. http://membranefilters.in/

Mulder M (2000) Basic principles of membrane technology. Kluwer, Dordrecht

Ndabigengesere A, Narasiah KS (1998) Quality of water treated by coagulation using Moringa oleifera seeds. Water Res 32:781-791

NEERI (22.04.2017) "NEERI-Zar" Portable Instant Water Filter. National Environmental Engineering Research Institute http:// www.neeri.res.in/content/neeri-zar

Pagsuyoin SA, Santos JR, Latayan JS, Barajas JR (2015) A multiattribute decision-making approach to the selection of point-ofuse water treatment. Environ Syst Decis 35:437-452

Peter-Varbanets M, Zurbrugg C, Swartz C, Pronk W (2009) Decentralized systems for potable water and the potential of membrane technology. Water Res 43:245-265

PFP (28.10.2014) Ceramic Water Filter Project. Potters for Peace http:// pottersforpeace.com/

PUR (31.10.2014) Combined flocculant-disinfection (PUR) sachet. Akvopedia. http://akvopedia.org/wiki/PUR_(Flocculant/Disin fectant)

Pureit (28.10.2014) HUL Pureit Classic 23L. Hindustan Unilever Limited http://www.pureitwater.com/IN/products\%E2\%80\%8E/purei $\mathrm{t}$-classic-231

Saini R, Rao AB, Kedare SB (2013) Development of pedal powered water filtration unit. Indian Institute of Technology Bombay, Mumbai, pp 20-22

Sankar MU, Aigal S, Maliyekkal SM, Chaudhary A, Anshup, Kumar AA, Chaudhari K, Pradeep T (2013) Biopolymer-reinforced synthetic granular nanocomposites for affordable point-of-use water purification. PNAS 110(21):8459-8464

Simonis JJ, Basson AK (2011) Evaluation of a low-cost ceramic microporous filter for elimination of common disease microorganisms. Phys Chem Earth 36:1129-1134

Sobsey M (2002) Managing water in the home: accelerated health gains from improved water supply. World Health Organization, Geneva

Sobsey MD, Stauber CE, Casanova LM, Brown JM, Elliott MA (2008) Point of use household drinking water filtration: a practical, effective solution for providing sustained access to safe drinking water in the developing world. Environ Sci Technol 42:4261-4267

SODIS (20.11.2019) By SODIS Eawag-Own work, CC BY 3.0, https ://commons. wikimedia.org/w/index.php?curid $=3857398$

Swach (28.10.2014) Tata Swach Cristella Plus. Tata Chemicals Limited http://www.tataswach.com/shopping/product_index.aspx\#

Terafil (28.10.2014) Low Cost 'Terafil' Water Filter. CSIR-Institute of Minerals and Materials Technology http://www.immt.res.in/ TERAFILWaterFilter.aspx

Water Pollution (2013) Water in India: situation and prospects. UNICEF, FAO and SaciWATERs, Geneva, pp 39-47

Waterlife (29.10.2014) Waterlife Little Star Gold. Waterlife India http:// www.waterlifeindia.com/little_star_gold.html

Publisher's Note Springer Nature remains neutral with regard to jurisdictional claims in published maps and institutional affiliations. 